\title{
Involvement of calcium, calmodulin and protein phosphorylation in morphogenesis of Candida albicans
}

\author{
Vijay Paranjape, Bipasha Gupta Roy and Asis Datta* \\ Molecular Biology Laboratory, School of Life Sciences, Jawaharlal Nehru University, New Delhi 110 067, India
}

(Received 21 March 1990; revised 11 July 1990; accepted 31 July 1990)

\begin{abstract}
$N$-Acetyl-D-glucosamine-induced germ tube formation in Candida albicans at $37^{\circ} \mathrm{C}$ was accompanied by an increase in the rate of protein phosphorylation. The calmodulin antagonist trifluoperazine and the $\mathrm{Ca}^{2+}$ ionophore A23187, which inhibited germ tube formation, also reduced the rate of phosphorylation. The rate of phosphorylation was also reduced when cells were incubated at $25^{\circ} \mathrm{C}$, which favoured yeast-phase growth. Twodimensional SDS-PAGE analysis of phosphoproteins from germ-tube-forming and yeast cells revealed two germtube-specific and three yeast-specific phosphoproteins. Germ tubes and hyphae had more calmodulin activity than yeast cells, irrespective of the germ-tube-inducing condition used. As a first step towards understanding the inhibitory effect of trifluoperazine on germ tube formation, calmodulin from $C$. albicans was purified to homogeneity. It was heat stable, and displayed a pronounced $\mathrm{Ca}^{2+}$-induced shift in electrophoretic mobility.
\end{abstract}

\section{Introduction}

Candida albicans is a widespread opportunistic fungal pathogen that grows either as a yeast or as filamentous hyphae, depending on the environmental conditions (Odds, 1985, 1988). A germ tube is an intermediate stage in the yeast-to-hypha transition which can be induced by a number of factors. Morphogenesis in C. albicans has attracted particular attention since it seems to be relevant to the virulence of the organism. It also provides a good model system for studying eukaryotic cell differentiation. Several experimental approaches have been applied to the investigation of morphogenesis of $C$. albicans, but the underlying mechanism is still not clear (Shepherd et al., 1985; Odds, 1988; Datta et al., 1989).

$\mathrm{Ca}^{2+}$ is a second messenger (Carafoli, 1987) whose concentration regulates the activity of many protein kinases (Greengard, 1978). Protein kinase action is a primary mechanism for transduction of extracellular stimuli. The action of $\mathrm{Ca}^{2+}$ is mediated mainly through calmodulin, a calcium-binding protein that regulates many cellular processes in eukaryotes (Cheung, 1980; Means and Dedman, 1980). Calmodulin has been detected in many yeasts and filamentous fungi (Hubbard et al., 1982; Muthukumar et al., 1987), but its precise role in yeast in relation to $\mathrm{Ca}^{2+}$ is not known. However, several lines of investigation suggest that $\mathrm{Ca}^{2+}$ is an important regulatory ion in yeast (Davis et al., 1986). The

Abbreviation: TFP, trifluoperazine. presence of calmodulin and of calmodulin-dependent protein kinases in Saccharomyces cerevisiae (Hubbard et al., 1982; Miyakawa et al., 1989) and Neurospora crassa (Ortega Perez et al., 1981; Tuinen et al., 1984) indicates that calmodulin has a regulatory role in fungi.

The activator function of $\mathrm{Ca}^{2+}$-calmodulin is antagonized by a variety of pharmacological agents, including phenothiazine derivatives such as trifluoperazine (TFP) (Weiss et al., 1980). Accordingly, inhibition of specific physiological processes by such calmodulin antagonists has provided the evidence for the possible involvement of $\mathrm{Ca}^{2+}$-calmodulin in such processes: However, calmodulin is not the only site of action of these calmodulin antagonists, as TFP is known to inhibit protein kinase C (Schatzmann et al., 1981). $\mathrm{Ca}^{2+}$ and calmodulin have been reported to be involved in differentiation of fungi such as Ceratocystis ulmi (Methukumar \& Nickerson, 1984), Dictyostelium discoideum (Lydan \& O’Day, 1988) and Physarum polycephalum (Uyeda \& Furya, 1986). Protein phosphorylation is also reported to be involved in the growth and differentiation of Mucor (Orlowski \& Sypherd, 1978), D. discoideum (Sinclair \& Rickwood, 1985 ) and $P$. polycephalum (Fronk \& Toczko, 1987). It has been reported recently that $\mathrm{Ca}^{2+}$ and calmodulinmediated protein phosphorylation play a role in germination and growth of Metarhizium anisopliae (St Leger et al., 1989).

We reported earlier that TFP blocks morphogenesis in C. albicans (Gupta Roy \& Datta, 1987). In this report, we 
have purified calmodulin from $C$. albicans and have shown that $\mathrm{Ca}^{2+}$ and calmodulin may regulate morphogenesis in $C$. albicans by differential protein phosphorylation.

\section{Methods}

Organism and growth conditions. C. albicans ATCC 10261 was maintained on a medium containing $2 \%$ peptone, $1 \%$ yeast extract, $2 \%$ glucose and $2 \%$ agar (all w/v). The cells were grown for $17 \mathrm{~h}$ in a medium containing $1 \%$ glucose, $0.5 \%$ peptone and $0.3 \% \mathrm{KH}_{2} \mathrm{PO}_{4}$ (GPK) and then transferred to a new medium (with half the concentration of glucose) and grown for $11 \mathrm{~h}$ into stationary phase.

Induction of germ tubes or hyphae. Germ tubes were induced as described elsewhere (Shepherd et al., 1980; Natarajan et al., 1984). Approximately $5 \times 10^{7}$ cells ml-1 were incubated at $37^{\circ} \mathrm{C}$ in a $20 \mathrm{~mm}$ imidazole/ $/ \mathrm{HCl}$ buffer (pH 6.6) containing $0.2 \mathrm{~mm}-\mathrm{MnCl}_{2}$ and $5 \mathrm{~mm}-\mathrm{N}$ acetyl-D-glucosamine (GlcNAc) as inducer. Germ tube formation was inhibited either by addition of $20 \mu \mathrm{M}$-TFP or calcium ionophore A23187 $(4 \mu \mathrm{M})$ to the induction medium or by incubating cells at $25^{\circ} \mathrm{C}$. For some experiments, an amino acid synthetic medium (Lee et al., $1975)$ at $\mathrm{pH} 6.8$ was used to induce germ tube formation at $37^{\circ} \mathrm{C}$.

Calmodulin purification. Calmodulin was purified by modification of methods used to purify calmodulin from bovine brain (Gopalakrishna \& Anderson, 1982) and S. cerevisiae (Davis et al., 1986). C. albicans was cultured in GPK medium at $30^{\circ} \mathrm{C}$ for $15 \mathrm{~h}$ in a fermenter (Bioengineering). Cells ( $80 \mathrm{~g}$ wet weight) were suspended in $80 \mathrm{ml}$ of homogenization buffer (50 mM-Tris, pH 7.5, 1 mM-EDTA and $1 \mathrm{mM}$ phenylmethylsulphonyl fluoride (PMSF). Glass beads $(80 \mathrm{~g} ; 0.45 \mathrm{~mm})$ were added and the cells were lysed by four $30 \mathrm{~s}$ pulses in a cell homogenizer (Braun) in four batches. About $90 \%$ of the cells were broken. The lysate was centrifuged at $12000 \mathrm{~g}$ for $30 \mathrm{~min}$; the supernatant was incubated in a boiling water bath for $3 \mathrm{~min}$ and then cooled in ethanol/ice bath for $10 \mathrm{~min}$. Precipitated material was removed by centrifugation at $12000 \mathrm{~g}$ for $30 \mathrm{~min}$. The $\mathrm{pH}$ of the supernatant was then adjusted to 7.5 with Tris base, $\mathrm{CaCl}_{2}$ was added to give a final concentration of $5 \mathrm{~mm}$, and the mixture was loaded on a column ( $25 \mathrm{ml}$ ) of phenyl-Sepharose (Pharmacia) at room temperature. The column was washed with a solution containing $50 \mathrm{~mm}-\mathrm{Tris} / \mathrm{HCl}$, $\mathrm{pH} 7.5,0.1 \mathrm{~mm}-\mathrm{CaCl}_{2}$ and $1 \mathrm{~mm}-\mathrm{PMSF}$ and then with the same buffer solution containing $0.5 \mathrm{M}-\mathrm{NaCl}$. Calmodulin was eluted with a buffer containing $50 \mathrm{mM}$-Tris/HCl, pH 7.5, $1 \mathrm{~mm}$-PMSF and 7.5 mM-EGTA. A single peak fraction was collected and dialysed against water at $4{ }^{\circ} \mathrm{C}$. The dialysed sample was lyophilized, dissolved in $10 \mathrm{~mm}-\mathrm{Tris} / \mathrm{HCl}$, pH 7.5, and then passed through a membrane filter ( $30 \mathrm{kDa}$ cut-off), using an ultrafiltration cell (Amicon). The filtrate contained calmodulin. To identify the protein as calmodulin, a sample $(1 \mu \mathrm{g})$ was subjected to SDS-PAGE in the presence of either $\mathrm{CaCl}_{2}(10 \mathrm{mM})$ or EGTA (10 mM) as described by Davis et al. (1986).

Calmodulin assay. Germ tubes/hyphae and yeast cells were harvested from $5 \mathrm{ml}$ induction medium after $3 \mathrm{~h}$ incubation. Cells were washed with sterile water, and the pellet was suspended in $0.2 \mathrm{ml}$ homogenization buffer (10 mM-Tris/HCl, pH 7.5, 0.5-mM-PMSF). Cells were then broken by mechanical disruption with glass beads $(0.45 \mathrm{~mm})$ and centrifuged at $12000 \mathrm{~g}$ for $3 \mathrm{~min}$. The supernatant was incubated in a boiling water bath for $3 \mathrm{~min}$, cooled in an ethanol/ice bath, and centrifuged at $12000 \mathrm{~g}$ for a further $3 \mathrm{~min}$. The resulting supernatant was assayed for calmodulin activity by its capacity to stimulate cAMPphosphodiesterase, using the method of Dedman \& Means (1977). Calmodulin activity was expressed as nmol cAMP hydrolysed min $^{-1}$ (mg protein $)^{-1}$. This experiment was repeated three times; data from a representative experiment are shown.
Rate of ${ }^{32} \mathrm{P}$ incorporation into proteins. Cells $\left(5 \times 10^{7}\right.$ cells $\left.\mathrm{ml}^{-1}\right)$ were suspended in imidazole-buffered medium with GlcNAc ( $5 \mathrm{mM}$ ), and incubated at $37^{\circ} \mathrm{C}$. TFP $(20 \mu \mathrm{M})$ or $\mathrm{A} 23187(4 \mu \mathrm{M})$ was added to the cell suspension at $0 \mathrm{~h} . \mathrm{CaCl}_{2}(10 \mathrm{mM})$ was added after $2.5 \mathrm{~h}$ incubation in the presence of $\mathrm{A} 23187$. The rate of ${ }^{32} \mathrm{P}$ incorporation was measured as described previously (Gupta Roy \& Datta, 1987).

Radioactive labelling for phosphoprotein analysis. Cells $\left(5 \times 10^{7}\right.$ cells $\left.\mathrm{ml}^{-1}\right)$ in imidazole-buffered GlcNAc ( $\left.5 \mathrm{mM}\right)$ medium were incubated at $37^{\circ} \mathrm{C}$ in a rotary shaker at 200 r.p.m. Germ tube formation was blocked either by addition of TFP $(20 \mu \mathrm{M})$ or by incubating cells at $25^{\circ} \mathrm{C}$. Cells were labelled with $\mathrm{H}_{3}{ }^{32} \mathrm{PO}_{4}\left(250 \mu \mathrm{Ci} \mathrm{ml}^{-1}\right)$ for $3 \mathrm{~h}$, harvested, and washed with ice-cold 5 mM-sodium phosphate. The final pellet was suspended in homogenization buffer containing $10 \mathrm{mM}-$ Tris/ $\mathrm{HCl}, \mathrm{pH} 6.8,0.5 \mathrm{~mm}-\mathrm{PMSF}$, RNAase $\left(50 \mu \mathrm{g} \mathrm{ml}^{-1}\right)$ and DNAase $\left(50 \mu \mathrm{g} \mathrm{ml}^{-1}\right)$. Glass beads $(0.45 \mathrm{~mm})$ were added and cells were broken by five 1 min periods of vortexing, each interspersed with $1 \mathrm{~min}$ in an ice bath. Glass beads, unbroken cells and cell debris were removed by centrifugation at $12000 \mathrm{~g}$ for $10 \mathrm{~min}$ at $4^{\circ} \mathrm{C}$.

Gel electrophoresis. Cell extracts were lyophilized, dissolved in $30 \mu \mathrm{l}$ IEF sample buffer (O'Farrell, 1975) and subjected to non-equilibrium pH-gradient electrophoresis (O'Farrell et al., 1977). Proteins were separated by isoelectric focusing in tube gels in the first dimension with $5 \%$ ampholytes, $\mathrm{pH} \mathrm{3-10} \mathrm{(Pharmacia).} \mathrm{The} \mathrm{second} \mathrm{dimension} \mathrm{was} \mathrm{run}$ in slab gels containing $10.5 \%(\mathrm{w} / \mathrm{v})$ polyacrylamide using the buffer system described by Laemmli (1970). After electrophoresis, the gels were treated for $30 \mathrm{~min}$ with $16 \%(\mathrm{w} / \mathrm{v})$ TCA at $95^{\circ} \mathrm{C}$ as described by Mannai \& Cozzone (1982). The gels were finally stained, destained and dried. Dried gels were exposed to Kodak X-Omat AR film at $-70^{\circ} \mathrm{C}$ with intensifying screens for autoradiography. Gels were loaded with equal amounts of TCA-precipitable radioactivity. Standard proteins (Pharmacia) were run with every second-dimension gel. These experiments have been repeated more than five times. All results were taken into account and only the changes that were consistent are indicated in the figures.

\section{Results}

Effect of trifluoperazone (TFP) and calcium ionophore (A23187) on germ tube formation and growth of $C$. albicans

We had earlier reported that TFP, a calmodulin inhibitor, blocks germ tube formation in C. albicans without affecting normal growth at $30^{\circ} \mathrm{C}$ (Gupta Roy \& Datta, 1987). To confirm that TFP is not toxic to cells at the concentration used, its effect on C. albicans growth was studied. There was no effect on growth at $37^{\circ} \mathrm{C}$, a temperature at which germ tube formation was blocked in the presence of TFP (Fig. 1). In the amino acid synthetic medium (Lee et al., 1975), at $\mathrm{pH} 6.8$, cells form only hyphae when incubated at $37^{\circ} \mathrm{C}$. Addition of TFP $(20 \mu \mathrm{M})$ not only blocked hypha formation but caused cells to grow as yeasts (data not shown). This supports the earlier observation that TFP specifically inhibits germ tube/hypha formation but not the growth of the organism. Calcium ionophore A23187 also blocked germ tube formation, an effect which was reversed by calcium 


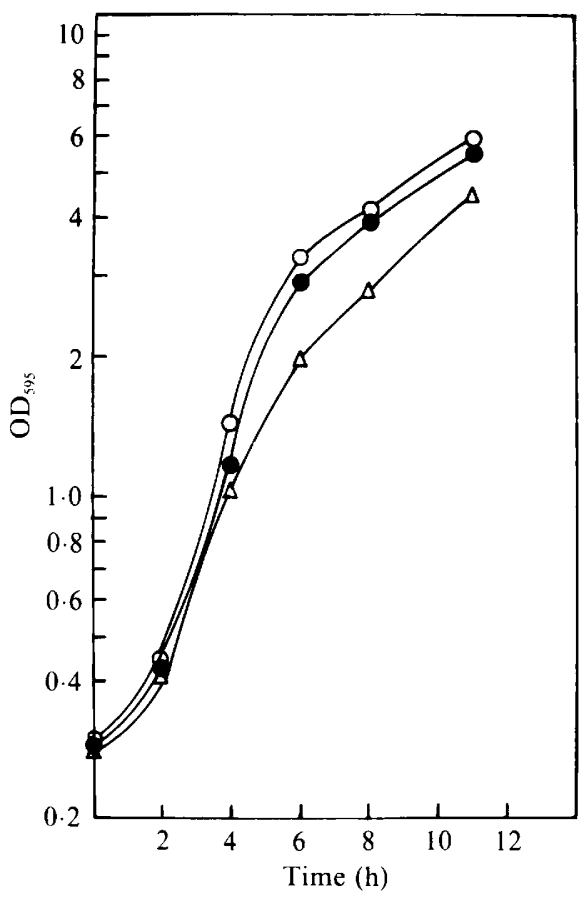

Fig. 1. Effect of TFP and A23187 on growth of C. albicans in medium containing $0.5 \%$ glucose, $0.5 \%$ peptone and $0.3 \% \mathrm{KH}_{2} \mathrm{PO}_{4}$ at $37{ }^{\circ} \mathrm{C} . \mathrm{O}$, Normal growth;, in presence of TFP $(20 \mu \mathrm{M}) ; \triangle$, in presence of calcium ionophore A23187 (4 $\mu \mathrm{M})$.

(Gupta Roy \& Datta, 1987), but A23187 had no significant effect on growth (Fig. 1). In a further test, cells were incubated in the presence of A23187 for $2.5 \mathrm{~h}$. $\mathrm{CaCl}_{2}(10 \mathrm{mM})$ was then added, and incubation continued for $3 \mathrm{~h}$. About $70 \%$ of the cells were able to form germ tubes (data not shown). Since TFP is a calmodulin inhibitor, we checked calmodulin activity in germ-tubeforming and yeast cells (Table 1). Germ tubes or hyphae formed in imidazole-buffered GlcNAc medium or in amino acid synthetic medium had more calmodulin activity than yeast cells.

\section{Calmodulin purification}

In order to confirm the presence of calmodulin in $C$. albicans, we purified it to homogeneity. The purified protein displayed a pronounced $\mathrm{Ca}^{2+}$-induced shift in electrophoretic mobility (Fig 2), which is an important criterion for identification of calmodulin (Davis et al., 1986). In the presence of $10 \mathrm{mM}-\mathrm{Ca}^{2+}$, the protein had an apparent molecular mass of $15 \mathrm{kDa}$, as judged by SDSPAGE, whereas in the presence of EGTA $(10 \mathrm{mM})$, the apparent molecular mass was $18.5 \mathrm{kDa}$. The two bands observed in the presence of $\mathrm{Ca}^{2+}$ were due to the limited concentration of $\mathrm{Ca}^{2+}$. The ability to bind calcium is an important property of calmodulin. To demonstrate $\mathrm{Ca}^{2+}$ binding directly, purified calmodulin was bound to nitrocellulose membrane and incubated in a solution containing ${ }^{45} \mathrm{Ca}^{2+}$. After washing, autoradiography of the membrane showed that $\mathrm{Ca}^{2+}$ was bound to calmodulin (data not shown).

\section{Protein phosphorylation during morphogenesis}

We showed previously that germ tube formation in $C$. albicans is accompanied by an increase in the rate of ${ }^{32} \mathrm{P}$ incorporation (Gupta Roy \& Datta, 1987). TFP, which blocks germ tube formation, also reduced the rate of ${ }^{32} \mathrm{P}$ incorporation, to a level comparable to that observed at $25^{\circ} \mathrm{C}$ (Fig. $3 a$ ). At $25^{\circ} \mathrm{C}$, cells remain in the yeast form and do not form germ tubes even in the presence of GlcNAc. A23187, which also blocks germ tube formation, also reduced the rate of ${ }^{32} \mathrm{P}$ incorporation. Interestingly, both of these effects of A23187 could be reversed by addition of $10 \mathrm{mM}^{-\mathrm{Ca}^{2+}}$ (Fig. $3 b$ ). This result suggests that $\mathrm{Ca}^{2+}$-calmodulin-dependent phosphorylation is involved in morphogenesis in C. albicans.

Fig. 4 represents a two-dimensional electrophoresis gel of total phosphoproteins extracted from germ-tubeforming and yeast cells. An equal amount of TCAprecipitable radioactivity was loaded on each gel to

Table 1. Calmodulin activity during morphogenesis of $\mathrm{C}$. albicans

\begin{tabular}{cccccc}
\hline \hline $\begin{array}{c}\text { Germ tube/hypha } \\
\text { forming medium }\end{array}$ & $\begin{array}{c}\text { Temperature } \\
\left({ }^{\circ} \mathrm{C}\right)\end{array}$ & $\mathrm{pH}$ & $\begin{array}{c}\text { TFP } \\
(20 \mu \mathrm{M})\end{array}$ & Morphology & $\begin{array}{c}\text { Calmodulin } \\
\text { Sp. act. }\end{array}$ \\
\hline Imidazole-buffered, GlcNAc & 37 & 6.6 & - & Germ tube & 4.3 \\
(Shepherd et al., 1980; & 37 & 6.6 & + & Yeast & 1.9 \\
Natarajan et al., 1984) & 25 & 6.6 & - & Yeast & 1.9 \\
Amino acid synthetic medium & 37 & 6.8 & - & Hypha & 4.3 \\
(Lee et al., 1975) & 37 & 4.5 & - & Yeast & 2.2 \\
& 25 & 6.8 & - & Yeast & 2.6 \\
\hline \hline
\end{tabular}

* Calmodulin specific activity was expressed as nmol cAMP hydrolysed $\min ^{-1}$ (mg protein) $)^{-1}$. This experiment has been repeated three times. Data of a representative experiment has been shown. 


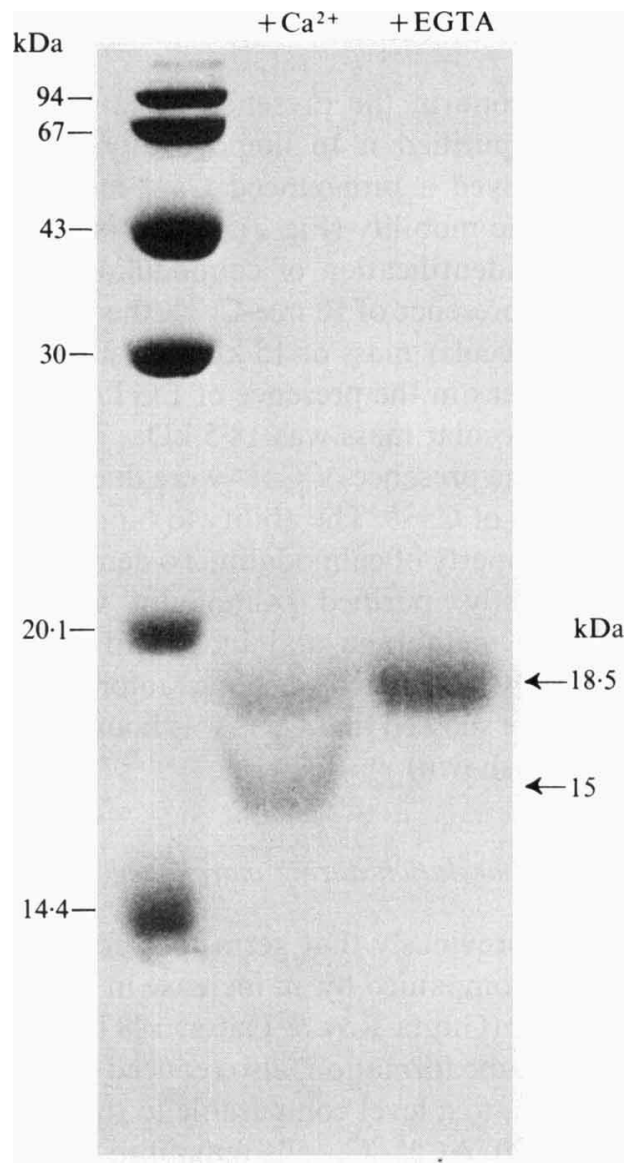

Fig. 2. Analysis of calmodulin by SDS-PAGE. Purified calmodulin $(1 \mu \mathrm{g})$ was subjected to electrophoresis in SDS-polyacrylamide gels $\left(14 \%\right.$ acrylamide) in the presence of either $10 \mathrm{mM}-\mathrm{CaCl}_{2}$ or $10 \mathrm{~mm}-$ EGTA. The monomer acrylamide : $N, N^{\prime}$-methylenebisacrylamide ratio was $38: 2$.

reveal qualitative changes in phosphoprotein profiles of germ-tube-forming and yeast-phase cells. Fig. 4(a) represents total phosphoproteins extracted from germtube-forming cells. Fig. 4(b) shows the pattern obtained when $20 \mu \mathrm{M}$-TFP, which inhibited germ tube formation, was added to the induction medium. Fig. $4(\mathrm{c})$ shows the pattern obtained when cells were incubated at $25^{\circ} \mathrm{C}$, the temperature that favours yeast phase growth. Comparison of the three autoradiographs shows that the majority of the phosphoproteins resolved are common to both germ-tube-forming and yeast-phase cells. However, germ tube formation was accompanied by an increase in the level of at least two phosphoproteins (19 kDa, $17.5 \mathrm{kDa}$ ) (marked $\mathrm{g}$ in Fig. 4). Similarly, yeast-phase cells also exhibited an increase in the level of three phosphoproteins ( $58 \mathrm{kDa}, 56 \mathrm{kDa}, 44 \mathrm{kDa}$ ) (marked b in Fig. 4). TFP, which inhibited germ tube formation, also

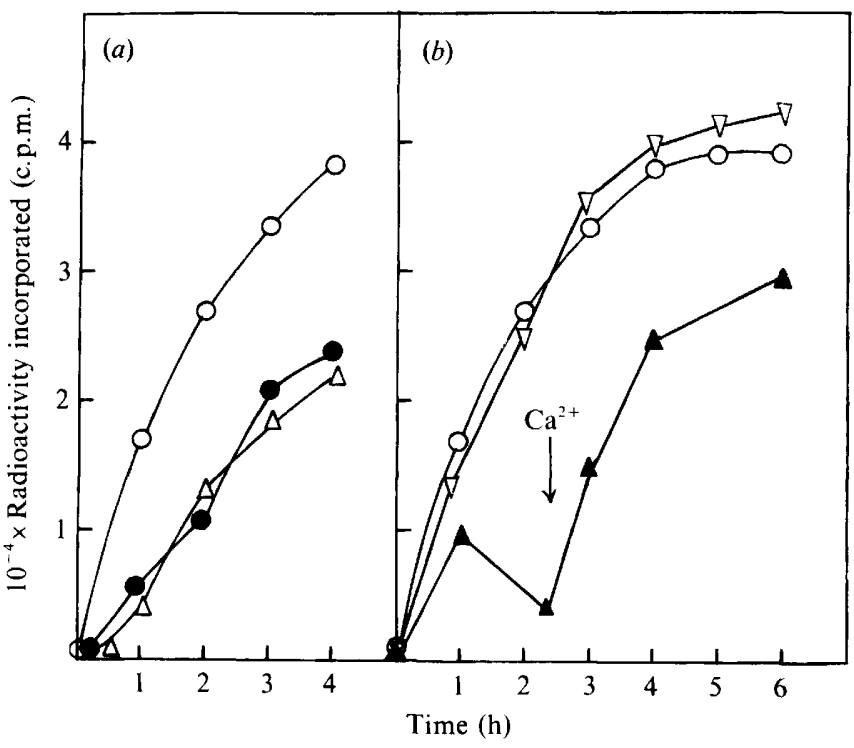

Fig. 3. Rate of ${ }^{32} \mathrm{P}$ incorporation during GIcNAc-induced germ tube formation in imidazole-buffered medium. At the indicated times, $1 \mathrm{ml}$ of cells $\left(5 \times 10^{7}\right.$ cells $\left.\mathrm{ml}^{-1}\right)$ was pulse-labelled with $\mathrm{H}_{3}{ }^{32} \mathrm{PO}_{4}$ $\left(0.6 \mu \mathrm{Ci} \mathrm{m} l^{-1}\right)$ for $20 \mathrm{~min}$ at $37^{\circ} \mathrm{C}$, and hot-TCA-precipitable counts were estimated. (a) Effect of TFP. $\bigcirc$, No addition; $\bigcirc$, TFP $(20 \mu \mathrm{M})$; $\triangle$, incubated at $25^{\circ} \mathrm{C}$. (b) Effect of A23187. $O$, No addition; $\nabla$, A23187 $(4 \mu \mathrm{M})$ plus $\mathrm{CaCl}_{2}(10 \mathrm{mM}) ; \Delta, \mathrm{A} 23187(4 \mu \mathrm{M}) ; \mathrm{CaCl}_{2}(10 \mathrm{mM})$ was added at the indicated time.

inhibited phosphorylation of two proteins $(19 \mathrm{kDa}$, $17.5 \mathrm{kDa}$ ), which appear to be germ tube specific. Inhibition of the phosphorylation of these proteins could be a non-specific effect of TFP and not associated with a change in morphology. To rule out this possibility, phosphoproteins from yeast-phase cells grown in the absence of TFP, but incubated at $25^{\circ} \mathrm{C}$, were analysed (Fig. 4c). Under these conditions the same two proteins $(19 \mathrm{kDa}, 17.5 \mathrm{kDa})$ were not phosphorylated. The phosphorylation/dephosphorylation of these proteins is therefore associated with a change in morphology, implying that TFP inhibits germ tube formation by inhibiting phosphorylation of specific proteins. The changes in the phosphorylation/dephosphorylation status of proteins reflected the cumulative changes in the physiology of the cell as it changed morphology, rather than being associated with a single discrete event during morphogenesis.

Although comparison of autoradiographs shows other differences, only those which were consistent have been marked. The hot TCA treatment of polyacrylamide gels confirmed that we were detecting ester-linked phosphopolypeptides, since acid phosphates and acyl-linked phosphates are unstable under these conditions (Mannai \& Cozzone, 1982). 


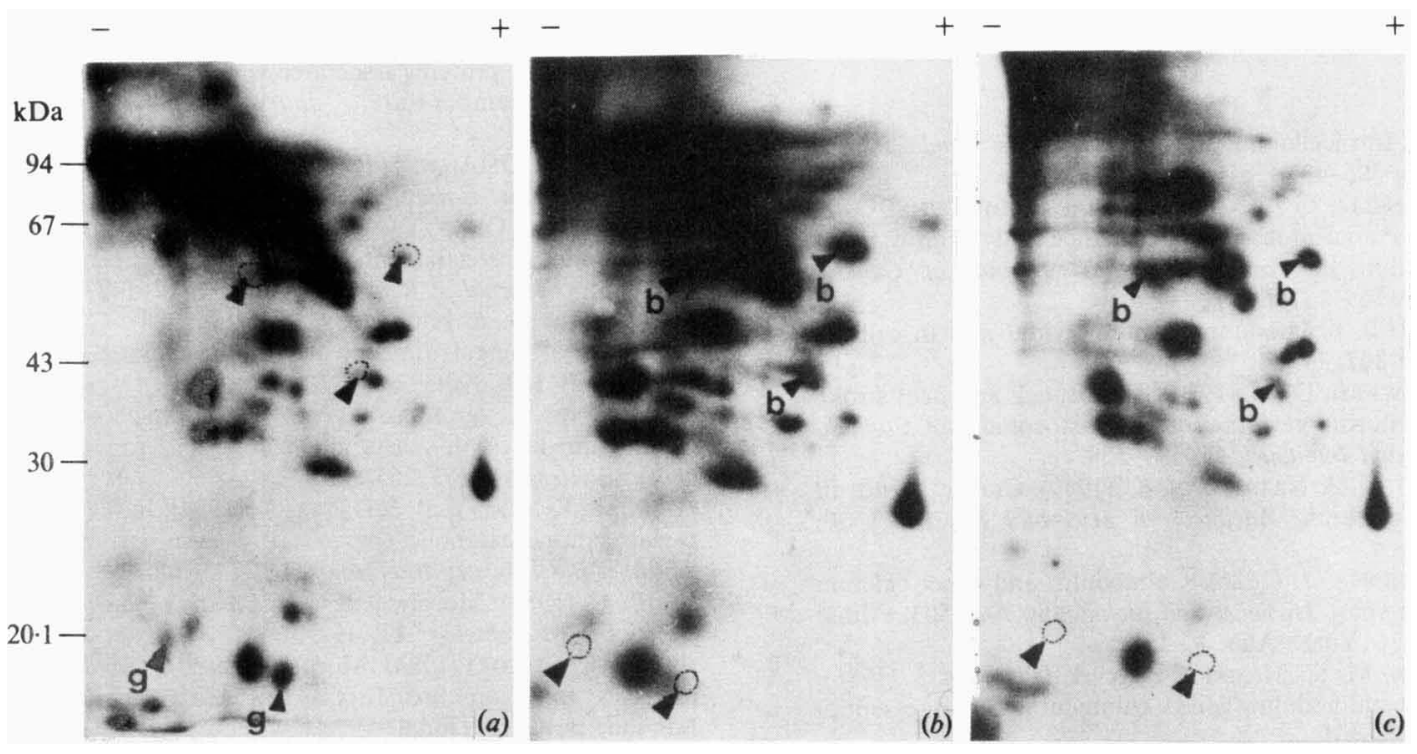

Fig. 4. Two-dimensional gel analysis of phosphoproteins from $C$. albicans during germ tube formation. Cells were labelled with $\mathrm{H}_{3}{ }^{32} \mathrm{PO}_{4}$ for $3 \mathrm{~h}$ in imidazole-buffered GlcNAc medium. Samples were subjected to electrophoresis as described in Methods. (a) Cells incubated at $37^{\circ} \mathrm{C} ;(b)$ cells incubated at $37^{\circ} \mathrm{C}$ in the presence of $20 \mu \mathrm{M}$-TFP; (c) cells incubated at $25^{\circ} \mathrm{C}(\mathrm{g}$, germ tube specific; b, yeast specific).

\section{Discussion}

Germ tube formation induced by GlcNAc, and hypha formation in amino acid synthetic medium, are blocked by TFP, a calmodulin inhibitor, and by A23187, a calcium ionophore, without affecting the growth of the organism. TFP also blocks the germ tube formation induced by proline and glucose plus glutamine (data not shown). All these results suggest the involvement of $\mathrm{Ca}^{2+}$ and calmodulin in morphogenesis of $C$. albicans. Chloropromazine, a calmodulin antagonist, is also known to block germ tube formation in C. albicans (Gupta Roy \& Datta, 1987).

A calmodulin-like protein has been reported in $C$. albicans (Hubbard et al., 1982). In order to confirm its presence, we have purified calmodulin from C. albicans. In an attempt to identify the molecular events through which TFP exerts its effect, the calmodulin activity associated with changes in morphology was determined. Irrespective of the induction conditions used, germ-tubeforming cells had more calmodulin activity than yeastphase cells. Morphology-associated changes in calmodulin activity could be due to changes in the intracellular levels of calmodulin or of $\mathrm{Ca}^{2+}$. Interestingly, it has been reported that fungi have more calmodulin when in the filamentous form than in the yeast form (Muthukumar $e t$ al., 1987). Although TFP is not a specific inhibitor of calmodulin (Schatzmann et al., 1981), our results indicate that TFP probably blocks germ tube formation by inhibiting calmodulin activity. It has been suggested that cytoplasmic alkalinization accompanying germ tube formation can mediate morphogenesis by altering calmodulin activity (Stewart et al., 1988). In Ceratocystis $u l m i$, addition of calcium can cause germination even in non-germination medium (Muthukumar \& Nickerson, 1984); however, calcium had no such effect on $C$. albicans. Higher fungi appear not to have an absolute requirement of calcium for growth (Fletcher, 1982) hence it seems that a low internal concentration of calcium is sufficient for calcium-dependent events.

Germ tube formation is accompanied by an increase in the rate of ${ }^{32} \mathrm{P}$ incorporation. The inhibition of $\left[{ }^{32} \mathrm{P}\right]$ incorporation both by $\mathrm{Ca}^{2+}$ depletion and by TFP suggests the involvement of $\mathrm{Ca}^{2+}$-calmodulin-dependent protein kinases, which is the primary mechanism of calmodulin action in other systems. At least two germtube-specific and three bud-specific phosphoproteins can be identified (Fig. 4). Moreover, "1P NMR spectroscopy studies have shown significant modulation in phosphorus-containing metabolites in the yeast-tomycelial transition in C. albicans (Cassone et al., 1983). The morphology-specific proteins reported elsewhere (Dabrowa \& Howard, 1980; Finney et al., 1985; Manning \& Mitchell, 1980) appear to be different from those reported here.

This work was supported by a grant from the Council of Scientific and Industrial Research, India. 


\section{References}

CARAFOL1, E. (1987). Intracellular calcium homeostasis. Annual Review of Biochemistry 56, 395-433.

Cassone, A., Carpinelli, G., Angiolella, L., Maddaluna, G. \& PoDo, F. (1983). ${ }^{31} \mathrm{P}$ nuclear magnetic resonance study of growth and dimorphic transition in Candida albicans. Journal of General Microbiology 129, 1569-1575.

Cheung, W. V. (1980). Calmodulin plays a pivotal role in cellular regulation. Science 207, 19-27.

Dabrowa, N. \& HowaRD, D. H. (1984). Heat shock and heat stroke proteins observed during germination of blastoconidia of Candida albicans. Infection and Immunity 44, 537-539.

Datta, A., Ganesan, K. \& Natarajan, K. (1989). Current trends in Candida albicans research. Advances in Microbial Physiology 30, 53-88.

DAVIS, T. N. \& THORNER, J. (1986). Calmodulin and other calcium binding proteins in yeast. In Yeast Cell Biology, pp. 447-503. Edited by J. B. Hicks. New York: Alan R. Liss.

Davis, T. N., Urdea, M. S., Masiarz, F. R. \& Thorner, J. (1986). Isolation of yeast calmodulin gene: calmodulin is an essential protein. Cell 47, 423-431.

Dedman, J. R. \& Means, A. R. (1977). Characterization of a spectrophotometric assay for cAMP phosphodiesterase. Journal of Cyclic Nucleotide Research 3, 139-152.

FinNey, J., Langtimm, C. J. \& Soll, D. R. (1985). The programs of protein synthesis accompanying the establishment of alternative phenotypes in Candida albicans. Mycopathologia 91, 3-15.

FLETCHER, J. (1982). Importance of calcium in microbiological systems. In The Role of Calcium in Biological Systems, vol. 1, pp. 229 239. Edited by L. J. Anghileri \& A. M. Tuffetanshileri. Boca Raton: CRC Press.

Fronk, J. \& ToczKo, K. (1987). Changes in the phosphorylation of non-histone proteins during differentiation of a lower eukaryote Physarum polycephalum. Biochemical and Biophysical Research Communications 142, 188-193.

Gopalkrishna, R. \& ANDERSON, W. B. (1982). Ca ${ }^{2+}$-induced hydrophobic site on calmodulin: application for purification of calmodulin by phenyl-Sepharose affinity chromatography. Biochemical and Biophysical Research Communications 104, 830-836.

GreEnGard, P. (1978). Phosphorylated proteins as physiological effectors. Science 199, 146-152.

Gupta Roy, B. \& DatTA, A. (1987). A calmodulin inhibitor blocks morphogenesis in C. albicans FEMS Microbiology Letters 41, 327329.

Hubbard, M., Bradley, M., Sullivan, P., Shepherd, M. \& FORRESTER, I. (1982). Evidence for the occurrence of calmodulin in yeast C. albicans and Saccharomyces cerevisiae. FEBS Letters 137, 85-88.

LAEMMLI, U. K. (1970). Cleavage of structural proteins during the assembly of the head of bacteriophage T4. Nature, London 277, 680685 .

LeE, K. L., BuCKLey, H. R. \& CAmpbell, C. C. (1975). An amino acid liquid synthetic medium for the development of mycelial and yeast forms of C. albicans. Sabouraudia 13, 148-153.

LYDAN, M. A. \& O'DAY, D. H. (1988). Differential developmental functions for calmodulin in Dictyostelium: trifluoperazine and $\mathbf{R}$ 24571 both inhibit cell and pronuclear fusion but enhance gamete formation. Experimental Cell Research 178, 51-63.

MANNAI, M. \& CoZZONE, A. J. (1982). Endogenous protein phosphorylation in Escherichia coli extracts. Biochemical and Biophysical Research Communications 107, 981-988.

ManNing, M. \& Mitchell, T. G. (1980). Morphogenesis of C. albicans and cytoplasmic proteins associated with differences in morphology, strain, or temperature. Journal of Bacteriology 144, 258-273.

Means, A. R. \& Dedman, J. R. (1980). Calmodulin - an intracellular calcium receptor. Nature, London 285, 73-77.

MiYakawa, T., OKa, Y., TsuchiYa, E. \& FukUi, S. (1989). Saccharomyces cerevisiae protein kinase dependent on $\mathrm{Ca}^{2+}$ and calmodulin. Journal of Bacteriology 171, 1417-1422.

Muthuxumar, G. \& Nickerson, K. W. (1984). Ca(II)-calmodulin regulation of fungal dimorphism in Ceratocystis ulmi. Journal of Bacteriology 159, 390-392.

Muthukumar, C., Nickerson, A. W. \& Nickerson, K. W. (1987). Calmodulin levels in yeasts and filamentous fungi. FEMS Microbiology Letters 41, 253-255.

Natarajan, K., RaI, Y. P. \& DatTA, A. (1984). Induction of $N$-acetyl$D$-glucosamine catabolic enzymes and germinative response in $C$. albicans. Biochemistry International 9, 735-744.

ODDs, F. C. (1985). Morphogenesis in Candida albicans. CRC Critical Reviews in Microbiology 12, 45-93.

ODDS, F. C. (EDITOR) (1988). Morphogenesis in Candida with special reference to C. albicans. In Candida and Candidiasis, pp. 42-59. London: Bailliere Tindal.

O'Farrell, P. H. (1975). High resolution two dimensional electrophoresis of proteins. Journal of Biological Chemistry 250, 4007-4021.

O'Farrell, P. Z., Goodman, H. M. \& O'Farrell, P. H. (1977). High resolution two dimensional electrophoresis of basic as well as acidic proteins. Cell 12, 1133-1142.

ORLOWSKI, M. \& SYPHERD, P. S. (1978). Regulation of translation rate during morphogenesis in fungus Mucor. Biochemistry 17, $560-574$.

Ortega Perez, R., Tuinen, V., Marme, D., Cox, J. A. \& Turian, G. (1981). Purification and identification of calmodulin from Neurospora crassa. FEBS Letters 133, 205-210.

Schatzmann, R. C. Wise, B. C. \& Kuo, J. F. (1981). Phospholipidsensitive calcium dependent protein kinase: inhibition by antipsychotic drugs. Biochemical and Biophysical Research Communications 98, 669-676.

ShePherd, M. G., ChIEw, Y. Y., Ram, S. P. \& Sullivan, P. A. (1980). Germ tube induction in Candida albicans. Canadian Journal of Microbiology 26, 21-26.

ShePherd, M. G., Poulter, R. J. M. \& Sullivan, P. A. (1985). Candida albicans: biology, genetics and pathogenicity. Annual Review of Microbiology 39, 579-614.

SINClaiR, J. H. AND RICxwood, D. (1985). Major changes in phosphorylation of chromatin associated non-histone proteins accompany development in slime mold Dictyostelium discoideum. Biochemical Journal 229, 771-778.

Stewart, E., Gow, N. A. R. \& Bowen, D. U. (1988). Cytoplasmic alkalinization during germ tube formation in Candida albicans. Journal of General Microbiology 134, 1079-1087.

St Leger, R., Roberts, D. W. \& Staples, R. C. (1989). Calcium and calmodulin-mediated protein synthesis and protein phosphorylation during germination, growth and protease production by Metarhizium anisopliae. Journal of General Microbiology 135, 2141-2154.

Tuinen, D., Ortega Perez, R., Marme, D. \& Turian, G. (1984). Calcium, calmodulin dependent protein phosphorylation in Neurospora crassa. FEBS Letters 176, 317-320.

UYEDA, T. Q. \& FURYA, M. (1986). Effect of low temperature and calcium on microfilament structure in flagellates of Physarum polycephalum. Experimental Cell Research 165, 461-472.

Weiss, B., Prozialeck, W., Cimino, M., Barnette, M. S. \& Wallace, T. L. (1980). Pharmocological regulation of calmodulin. Annals of the New York Academy of Sciences 356, 319-345. 